\title{
TERMINOLOGY: OLD NORSE
}

\author{
aðalhending 'full rhyme,' that is, internal rhyme with identical vowels and \\ postvocalic environment in even lines \\ áttmaelt \\ bragarbót \\ detthent \\ drápa \\ draugsháttr \\ flokkr \\ 'eight-clause stanza,' dróttkvoett variant in which each line contains \\ an independent clause (SnE I:614) \\ dróttkvaett variant of odd lines with a trisyllabic compound in \\ positions $2-4$, alliteration in positions 1 and 5 , and internal \\ rhymes in positions 3 and 5 ( $S n E \mathrm{I}: 642$ ) \\ dróttkvaett variant of odd lines with a trisyllabic compound in \\ positions 3-6 ( $S n E$ I:640) \\ longer encomiastic poem with refrain (stef) \\ even dróttkvatt lines of Type A, with enclitic inflectional endings in \\ positions 2 and 4 (SnE I:640) \\ fornyrðislag Norse alliterative meter developed from the Germanic alliterative \\ long line \\ frumhending \\ helmingr \\ hending \\ hjástaelt \\ hrynhent \\ first internal rhyme in a line \\ half-stanza consisting of four lines \\ internal rhyme \\ 'pattern with sequential insertion,' in which positions 2-6 in line 4 \\ are occupied by an independent clause that deals with ancient \\ lore (SnE I:618) \\ expanded version of dróttkvaett in which each line contains eight \\ syllables ( $S n E$ I:676-78) \\ h०fuðstafr \\ kenning \\ 'main stave,' fixed in initial position, even lines, in regular \\ dróttkvatt \\ nominal circumlocution, consisting of a base word and one or more \\ qualifiers \\ kviðuháttr \\ skaldic syllable-counting meter in which the odd lines consist of \\ three syllables and the even lines of four syllables \\ lausavísa \\ 'loose stanza'
}


ljódaháttr

orঠskviðuháttr

riðhent

runhent

sextánmaelt

skjalfhent

skothending

stamhent

stef

stuðill

staelt

tilsagt

tviskelft

viðrhending

vísufjórðungr

vísuorð
Norse meter with six-line stanzas, in which lines 1-2 (and 4-5) alliterate, and lines 3 and 6 contain internal alliteration $(S n E$ I:714)

dróttkvatt variant with inserted proverbs in positions 2-6, even lines ( $\operatorname{SnE} \mathrm{I}:$ 636)

dróttkvaett variant in even lines with a trisyllabic compound in positions 2-4 and internal rhymes in positions 3 and 5 ( $\mathrm{SnE}$ I:642-44)

meter with end rhyme (SnE I:696-710)

'sixteen-clause pattern,' dróttkvaett variant in which each line contains two independent clauses (SnE I:614)

dróttkvatt variant of odd lines with alliteration in positions 1 and 3 and a long enclitic syllable in position 2 ( $S n E \mathrm{I}: 646)$

internal rhyme with different vowels and similar postvocalic environment in odd lines

dróttkvatt variant of odd lines with rhyme and alliteration in positions 4-5 (SnE I:658)

'refrain'

alliterating stave(s) in odd lines

'pattern with insertion,' in which lines 1 and 4 belong together syntactically, and lines 2-3 form an independent statement ( $\mathrm{SnE}$ I:616-18)

'pattern with embedded explanation,' in which positions 1-4 in even lines contain an explanatory inserted clause ( $S n E$ I:634-36)

dróttkvcett variant with skjalfhent in all odd lines (SnE I:638)

the second internal rhyme in a line, usually fixed in position 5

'couplet'

'poetic line' 